DOI: 10.32089/WBH.PHW.2019.3(269).0002

orcid.org/0000-0002-0465-4701

LESZEK MADEJ

\title{
Ustrój i działalność sądownictwa rosyjskiej floty wojennej w latach 1867-1914 (część 1)
}

\section{Przebieg prac nad reformą systemu Temidy marynarki wojennej w latach pięćdziesiątych i sześćdziesiątych XIX wieku}

Myśl przewodnia artykułu koncentruje się na możliwie najpełniejszym zaprezentowaniu organizacji i zasad funkcjonowania organów wymiaru sprawiedliwości rosyjskiej marynarki wojennej po jej zreformowaniu w 1867 r., z uwzględnieniem metod kształcenia i poziomu wiedzy fachowej personelu zmodernizowanych instytucji sądowniczych, co bezpośrednio przekładało się na ich efektywność.

Prace nakierowane na radykalną restrukturyzację ustroju sądownictwa morskiego rozpoczęły się właściwie już w 1857 r., kiedy przy Departamencie Audytorskim Ministerstwa Morskiego powołano specjalną komisję do przeglądu obowiązującego we flocie prawodawstwa karnego, a w szczególności ustaw odnoszących się do procedur sądowych. Jednocześnie oddelegowano za zagranicę kilku specjalistów z zadaniem zapoznania się z ustawodawstwem z jakiego korzystały najsilniejsze marynarki wojenne świata. $\mathrm{W}$ oparciu o uzyskane tym sposobem informacje generał audytor floty $\mathrm{Pa}$ weł Glebow na początku lat sześćdziesiątych sporządził projekt regulaminu, który dotykał tak całościowej organizacji wymiaru sprawiedliwości, jak i zasad postępowania sądowego ${ }^{1}$.

Niemniej jednak sprawa modernizacji sądownictwa marynarki cesarskiej została oficjalnie podniesiona dopiero pięć lat później. 2 listopada 1862 r., a więc kilka dni po zatwierdzeniu głównych założeń reformy

\footnotetext{
С.Ф. Огродников, Исторический обзор развития и деятельности Морского Министерства за сто лет его существования (1802-1902), Санкт-Петербург 1902, s. 177.
} 
w powszechnym wymiarze sprawiedliwości, Aleksander II zezwolił na utworzenie komisji grupującej przedstawicieli Ministerstw Wojny i Morskiego. Zobligowano ją do nakreślenia ogólnych wytycznych, na jakich miały się opierać piony sądowe armii i marynarki wojennej. Ścisła współpraca pomiędzy tymi dwoma resortami wynikała z potrzeby możliwie najdalej posuniętej unifikacji funkcjonujących $w$ ich ramach instytucji wymiaru sprawiedliwości i obowiązujących w nich procedur sądowych, które musiały ponadto odpowiadać nowym kanonom powszechnego wymiaru sprawiedliwości. Projekt bazowych ustaw, określających fundamenty ustroju sądów armii i floty, został przygotowany w kwietniu 1863 r. Najpierw skierowano go do rozpatrzenia przez specjalny zespół, składający się z oficerów i urzędników zatrudnionych $\mathrm{w}$ obu wymienionych ministerstwach oraz resortach cywilnych, którzy dysponowali stosowną wiedzą prawniczą oraz praktycznym doświadczeniem sądowym. Potem - zgodnie z wolą cesarza - trafił on do rąk przedstawicieli wyższego dowództwa armijnego i floty. Na koniec, po uwzględnieniu uwag tych ostatnich dwu instytucji, projekt przedłożono w trybie ustawodawczym połączonemu Kolegium Audytoriatów Generalnych sił lądowych i marynarki, poszerzonemu o niektórych członków Rady Wojennej oraz kilka innych osób ${ }^{2} .25$ października 1865 r. organ ten przedstawił monarsze podstawowe założenia przyszłej reformy. Zapoznawszy się z nimi, Aleksander II wydał dyspozycje przygotowania ustawy sądowej dla floty. Powinnością tą obarczono wspomnianego powyżej generał-audytora Glebowa, z zastrzeżeniem, że w trakcie prac powinien kontaktować się z generał-audytorem armii Władimirem Fiłosofowem, co po raz kolejny potwierdzało dążenie najwyższych czynników do ujednolicenia struktur i procedur sądowych w resortach odpowiedzialnych za bezpieczeństwo państwa. Oczywiście szefowie obu audytoriatów działali pod bezpośrednim nadzorem ministrów sił lądowych i marynarki³

Projekt regulaminu z dziedziny organizacji organów wymiaru sprawiedliwości oraz procedur sądowych floty udało się sporządzić na początku 1866 r. W kwietniu tego roku wniesiono go - w celu rozpatrzenia - do połączonego Kolegium Audytoriatów Generalnych, a po wprowadzeniu niezbędnych poprawek i uzupełnień członkowie tego gremium uznali za wskazane jego przedyskutowanie $\mathrm{z}$ wyższymi reprezentantami resortów cywilnych odpowiedzialnych za sądownictwo. Chodziło o zharmonizowanie

\footnotetext{
2 Обзор деятельности морскаго управления в России в первые двадиатипятилетие благополучного изарствования государия императора Александра Николаевича 18551880, cz. 2, Санкт-Петербург 1880, s. 676-677.

3 Ibidem, s. 677. Wszystkie daty dzienne zostały podane według „starego stylu”. W XIX w. różnica pomiędzy kalendarzami juliańskim i gregoriańskim wynosiła 12 dni, a w następnym stuleciu 13 dni.
} 
norm prawnych i modelu organizacyjnego Temidy floty z rozwiązaniami strukturalnymi i ustawodawstwem, które funkcjonowały już w powszechnym systemie wymiaru sprawiedliwości. W tym celu 4 lipca 1866 r. został powołany do życia specjalny komitet mający koordynować interesy i potrzeby resortów morskiego i wojskowego $\mathrm{z}$ dążeniami i zamierzeniami ministerstw cywilnych. Na jego czele stanął generał admirał i przewodniczący Rady Państwa wielki książę Konstanty Nikołajewicz ${ }^{4}$. Po wielu konsultacjach i debatach oraz wprowadzeniu kolejnych korekt i uzupełnień car 15 maja 1867 r. sygnował Wojenno-morski regulamin sq̨dowy. Kilkanaście dni później, 22 lipca, Aleksander II zaaprobował: etaty Głównego Morskiego Sądu Wojennego, Głównego Wojenno-Morskiego Zarządu Sądowego, organów sądowych w portach sankt petersburskim i kronsztadzkim, wykaz uposażeń emerytalnych dla poszczególnych urzędników pionu sądowego floty, jak również rozporządzenie o wprowadzeniu nowego regulaminu sądowego w portach bałtyckich 5 .

\section{Struktura wymiaru sprawiedliwości floty wojennej po 1867 r.}

Zagadnienia dotyczące całościowej struktury sądownictwa floty zostały precyzyjnie sformułowane w pierwszej części Wojenno-morskiego regulaminu sądowego, składającego się z 205 artykułów, pogrupowanych tematycznie w dziewięciu rozdziałach. Ustawodawca odniósł się w nich do organizacji i trybu funkcjonowania: nowych sądów, prokuratury, urzędów śledczych, zasad mianowania, zwalniania oraz przenoszenia zatrudnionych w nich urzędników, wraz z określeniem ich uprawnień i przywilejów. Równocześnie znalazły się tam informacje na temat prawnych podstaw relacji organów Temidy marynarki wojennej z innymi resortami. Druga część kodeksu, łącząca cztery księgi (ogółem 982 artykuły), zawierała normy dotyczące trybu rozstrzygania o podsądności spraw karnych oraz pryncypiów prowadzenia śledztw wstępnych i spraw sądowych we flocie. Dodatkowo zamieszczono w niej opis procedur, jakie powinny obowiązywać w wypadku dopuszczenia się przez „rangi”6 resortu wojenno-morskiego przestępstw państwowych oraz czynów karalnych o mieszanej podsądności (głównie

4 Ibidem, s. 677-678; Bысшие и иентральные государственные учреждения России 1801-1917, t. 1, red. Н. Р. Ерошкин, Санкт-Петербург 2001, s. 22, 156; t. 2, red. Д. И. Раскин, Санкт-Петербург 2001, s. 81; t. 4, red. Д. И. Раскин, Санкт-Петербург 2004, s. 37, 201.

5 Обзор деятельности морскаго..., s. 679-680; Полное Собрание Законов Российской Империи (dalej: ПСЗРИ), (Собрание II), t. 41, otd. 1, nr 43473, Санкт-Петербург 18301885, s. $887-890$.

6 Pod pojęciem rang resortu wojenno-morskiego ustawodawca rozumiał wszystkich pełniących służbę we flocie: oficerów, podoficerów, marynarzy, żołnierzy i urzędników wojskowych. Takie rozumienie zachowano w tekście. 
wojskowej i cywilnej), jak również informacje o organizacji struktur wymiaru sprawiedliwości i toku postępowań przed sądami morskimi w warunkach wojennych. Wojenno-morski regulamin sądowy wprowadzał w marynarce trójszczeblowy model sądownictwa. Na wstępie należy zaznaczyć, że nowo powołane agendy wymiaru sprawiedliwości - w odróżnieniu od sądów powszechnych - zajmowały się rozpatrywaniem tylko spraw karnych. Casusy cywilne znajdowały się poza zasięgiem ich prerogatyw.

Sądy załogowe (ros. ekipażnyje sudy). Stanowiły najniższą instancję, odpowiadającą $\mathrm{w}$ armii sądom pułkowym, zaś $\mathrm{w}$ sądownictwie powszechnym sądom pokoju. Można było je powoływać przy każdej załodze morskiej (w tym także gwardyjskiej) i portowej. Sądy załogowe nosiły nazwy formacji, w ramach których funkcjonowały. Instytucjom tego typu, tworzonym w portach, podlegały sprawy o czyny karalne popełnione w oddziałach brzegowych, szkołach i zarządach floty. Ogólnie rzecz ujmując, w gestii sądów załogowych znajdowały się drobne przestępstwa i wykroczenia, jakich dopuścili się zaliczani do niższych rang (podoficerowie, marynarze), za które groziły kary poprawcze, niepociągające za sobą pozbawienia lub ograniczenia przywilejów bądź praw specjalnych wynikających z urodzenia albo wykształcenia, jak i odesłanie do rot wojenno-poprawczych, względnie zasądzenie surowszych sankcji. Składy orzekające, kreowane przy załogach i komandach, mogły wyrokować jedynie w stosunku do czynów karalnych, popełnionych przez - odbywających w nich służbę - podoficerów i marynarzy. Działania naruszające literę ustaw, jakich ci ostatni dopuścili się poza swymi jednostkami macierzystymi, podlegały $\mathrm{w}$ portach orzecznictwu lokalnego sądu załogowego lub wyznaczonego w ramach miejscowego batalionu gubernialnego, ewentualnie najbliższemu sądowi pułkowemu. Ponieważ podsądność wiązała się ściśle z miejscem popełnienia przestępstwa, to legislator dopuszczał możliwość karania niższych rang floty (czyli podoficerów, marynarzy i żołnierzy) przez organa wymiaru sprawiedliwości lądowych sił zbrojnych ${ }^{7}$. Wszelkie spory dotyczące podległości spraw właściwym sądom załogowym rozstrzygali główni komendanci portów, na podstawie wniosków składanych przez dowódcę jednostki, przy której działała rzeczona agenda wymiaru sprawiedliwości. Natomiast decyzja o tym, czy casus powinien trafić przed oblicze sądu załogowego, czy też pułkowego zależała od porozumienia pomiędzy wyższymi dowódcami armii i marynarki. Jeśli doszło do zatargu w kwestii podsądności sprawy na linii dowódca załogi - cywilna instytucja sądowa (sąd pokoju, względnie sędzia śledczy), to ten pierwszy powinien zwrócić się z prośbą o wydanie decyzji albo do odpowiedniego zjazdu sędziów pokoju (instytucja odwoławcza od wyroków sądów pokoju), albo do sądu okręgowego, przy którym pracował sędzia śledczy ${ }^{8}$.

Военно-морской судебный устав, Санкт-Петербург 1867, s. 4, 40-41.

$8 \quad$ Ibidem, s. 42. 
Sądy załogowe prowadziły rozprawy w trybie uproszczonym, bez udziału urzędników sądowych. Najważniejsza rola, tak w samym procesie rozpatrywania spraw, jak i ferowaniu końcowych werdyktów, należała do bezpośredniego zwierzchnika jednostki morskiej, przy której działał sąd. To on, jako jedyny, mógł wszczynać postępowania oraz wyznaczać na okres jednego roku przewodniczącego oraz na sześć miesięcy członków składu orzekającego, których dokładna liczba nie została podana $\mathrm{w}$ regulaminie. Rozprawy prowadzono w oparciu o tryb ustny, bez zbędnych formalności, dopuszczając udział osób postronnych, za wyjątkiem spraw o: bluźnierstwo, potępienie wiary, obrazę świątyni, stręczycielstwo, zachowania sprzeczne z naturą, złamanie przepisów dyscyplinarnych, naruszenie praw rodzinnych, obrazę kobiety i inne nieprzyzwoite działania w nią wymierzone, jak również w razie wszczęcia sprawy na podstawie skargi prywatnej, gdy strony zażyczyły sobie prowadzenia procesu przy drzwiach zamkniętych'. Ustawa przyznawała dowódcom załóg prawo nie tylko do zatwierdzania wyroków, ale także do ich zmiany, oczywiście w granicach przyznanej im władzy dyscyplinarnej, jeśli wyroki końcowe sądów załogowych nie przekraczały jej zakresu. W razie gdy zwierzchnik jednostki morskiej nie zgodził się z werdyktem sądu lub gdy przekroczył swe uprawnienia, sprawa trafiała do wyższej instancji, czyli do portowego sądu wojenno-morskiego. Zatwierdzone przez dowódców - maksymalnie w terminie trzydniowym sentencje końcowe uznawano za ostateczne. Prawodawca nie dopuszczał możliwości ich zaskarżenia przez skazanych. Jedynie osoby poszkodowane w wyniku przestępstwa dokonanego przez marynarza mogły wnosić do instytucji wyższego szczebla odwołanie od werdyktu. Zapadające większością głosów orzeczenia sądów załogowych, które uzyskały konfirmację (zatwierdzenie) dowódców, nabierały automatycznie mocy prawnej i były natychmiast wykonywane ${ }^{10}$.

Sądy wojenno-morskie (ros. wojenno-morskije sudy). Znalazły się one na wyższym poziomie Temidy marynarki wojennej, zajmując miejsce dotychczas funkcjonujących portowych komisji wojenno-sądowych. Tworzone w głównych portach Cesarstwa Rosyjskiego, nosiły ich nazwy. Odpowiednikami tych organów w lądowych siłach zbrojnych były okręgowe sądy wojskowe, a w cywilnym systemie wymiaru sprawiedliwości sądy okręgowe i izby sądowe; te ostatnie wyłącznie jako organa pierwszej instancji. W celu rozpatrywania spraw karnych $w$ miejscach oddalonych od siedzib sądów wojenno-morskich, na przykład w portach drugiej kategorii (Archangielsk, Ryga, Parnawa, Narwa i Wyborg, zaś od przełomu XIX i XX w. Rewel, Sweaborg [Helsingfors], Nikołajów, Batumi, Baku, Władywostok, czasowo

$9 \quad$ Ibidem, s. 45-46, 49-50, 100.

10 Ibidem, s. 54-57, 60. 
port Aleksandra III [Libawa] oraz Port Artur) albo w stacjach morskich, legislator zezwalał na powoływanie tymczasowych organów sądowych tego rodzaju, które w istocie były sesjami wyjazdowymi stałych sądów wojenno-morskich ${ }^{11}$.

W zakres zainteresowań sądów wojenno-morskich wchodziły wszystkie czyny karalne popełnione przez oficerów, podoficerów, marynarzy i urzędników floty, z wykluczeniem przypadków należących ustawowo do gestii sądów załogowych. Organa sprawiedliwości, o których mowa, łączyły w sobie członków stałych i tymczasowych. Do grona tych pierwszych należał przewodniczący oraz dwóch lub trzech sędziów marynarki, z tym zastrzeżeniem, że jeden $\mathrm{z}$ nich powinien być urzędnikiem cywilnym $\mathrm{z}$ wyższym wykształceniem prawniczym. Członków tymczasowych w liczbie dwóch sztabsoficerów i czterech oberoficerów liniowych mianował główny dowódca portu na okres sześciu miesięcy. Funkcję tę mogli sprawować jedynie oficerowie z co najmniej ośmioletnim ogólnym stażem służbowym, którzy mieli za sobą nie mniej niż cztery lata służby liniowej bądź dowodzili jednostką nie mniej niż trzy lata. $\mathrm{Na}$ okres zasiadania w składach orzekających zwalniano ich z wykonywania regulaminowych obowiązków służbowych. Naturalnie, w grę wchodzili oficerowie niekarani oraz tacy, przeciwko którym aktualnie nie prowadzono postępowania sądowego bądź śledztwa ${ }^{12}$. W razie braku stałych członków dopuszczono możliwość udziału w rozprawie sędziego śledczego prowadzącego dochodzenie, ale bez prawa partycypowania w zasądzeniu wyroku. Gdy planowano rozprawę nad admirałem lub generałem, prezesa sądu typowano z grona sędziów Głównego Morskiego Sądu Wojennego, zaś do grupy pozostałych członków niezależnie od należących do stałego składu sądu wojenno-morskiego sędziów i przewodniczącego - rekrutowano jeszcze: dwóch admirałów albo generałów, na mocy rozporządzenia ministra spraw morskich, dwóch admirałów bądź generałów (względnie dwóch sztabsoficerów) w oparciu o rozkaz głównego komendanta portu, jak i dwóch sztabsoficerów piastujących stanowiska sędziowskie w tymczasowym sądzie wojenno-morskim ${ }^{13}$. Funkcję przewodniczących

11 Ibidem, s. 5-6; С.Ф. Огродников, Исторический обзор развития..., s. 13; Свод морских постановлений (dalej: СМП), кн. 1: Общее образование управления морским ведомством, Санкт-Петербург 1902, s. 34.

12 Военно-морской судебный устав..., s. 6-7. Szczegółowe rozporządzenia odnoszące się do zasad nominacji tymczasowych członków sądów wojenno-morskich zostały wydane 3 II i 28 IV 1869 r. Stanowiska te zalecano obsadzać oficerami pełniącymi służbę w oddziałach portowych. Dwóch spośród nich powinno posiadać stopień kapitana I rangi albo pułkownika, zaś czterech, będących dowódcami okrętów - szarże sztabsoficerskie; zob. О временных членах военно-морского суда, „Морской Сборник” 1869, t. 101, nr 3, официальный отдел, s. 31-32; 1869, t. 102, nr 6, официальный отдел, s. 14; ПСЗРИ (II), t. 44, otd. 1, nr 47014, s. 377.

13 Военно-морской судебный устав..., s. 6-9, 14. 
mogli obsadzać sędziowie i prokuratorzy wojskowi, a stanowiska sędziowskie - kandydaci na sędziów, śledczy wojskowi oraz urzędnicy Głównego Wojenno-Morskiego Zarządu Sądowego ${ }^{14}$.

Nie zawsze udało się skompletować regulaminowy skład charakteryzowanych organów. Według etatów dwu najważniejszych sądów wojenno-morskich, mianowicie stołecznego i kronsztadzkiego, ogłoszonych drukiem 22 czerwca 1867 r. w pierwszym - oprócz prezesa - zasiadało po dwóch, natomiast $\mathrm{w}$ drugim - po trzech sędziów morskich i śledczych. Personel pomocniczy tworzył jeden sekretarz; w Sankt-Petersburgu asystował mu jeden, a w Kronsztadzie aż trzech pomocników. Dodatkowo przewidziano konieczność zatrudnienia jednego ( $w$ stolicy) i dwóch (w Kronsztadzie) kandydatów na stanowiska sędziowskie, zapewne w celu zdobycia przez nich praktycznego doświadczenia zawodowego. Roczne utrzymanie sądu w Sankt Petersburgu kosztowało skarb państwa 21700 rubli, a w Kronsztadzie 31250 rubli, uwzględniając pensje i wydatki na materiały kancelaryjne ${ }^{15}$.

Tryb prowadzenia spraw w sądach wojenno-morskich oparto na kanonach publicznego procesu oskarżycielskiego, wprowadzonych do cywilnego wymiaru sprawiedliwości na podstawie ustaw z listopada 1864 r., z tym jednak wyjątkiem, że śledztwo wstępne oraz skierowanie sprawy do sądu mogło nastąpić wyłącznie w oparciu o stosowne rozporządzenie wyższych dowódców marynarki. Podsądny posiadał prawo do wyboru obrońcy, którego mógł także na jego prośbę wyznaczyć przewodniczący składu orzekającego. Obowiązki oskarżyciela pełnił umiejscowiony przy każdym sądzie prokurator floty bądź jego zastępca. Ustne przewody sądowe odbywały się publicznie, poza przypadkami wyszczególnionymi powyżej w stosunku do rozpraw w sądach załogowych. Przy drzwiach zamkniętych toczyły się wszystkie posiedzenia administracyjne. Sentencje końcowe zapadały zwykłą większością głosów. Przy równym ich podziale decydowała opinia prezesa ${ }^{16}$. W przeciwieństwie do sądów załogowych, w wojenno-morskich organach wymiaru sprawiedliwości dowódcy wojskowi nie posiadali żadnego wpływu na przebieg procesu oraz wydanie wyroku. Werdykty sądów wojenno-morskich stawały się ostateczne i podlegały uchyleniu przez Główny Morski Sąd Wojenny albo na prośbę oskarżonego, albo na mocy protestu prokuratorskiego $\mathrm{z}$ racji nieprawidłowego stosowania ustaw lub nieprzestrzegania zwyczajów sądowych ${ }^{17}$. Od decyzji Głównego Morskiego

\footnotetext{
14 Ibidem, s. 21.

15 ПСЗРИ (II), t. 42, otd. 2, nr 44734, s. 520.

16 Военно-морской судебный устав.., s. 11, 13, 15, 110-111.

17 Ibidem, s. 137-147.
} 
Sądu Wojennego, który rozstrzygał skargi i protesty kasacyjne, nie istniała już możliwość odwołania.

Przy sądach wojenno-morskich działali, w charakterze członków etatowych, sędziowie śledczy floty zajmujący się prowadzeniem śledztw wstępnych we wszystkich wypadkach należących do prerogatyw tych instytucji sądowniczych. Odbywały się one w oparciu o procedurę ustną. Dochodzeniami mogli się także trudnić cywilni śledczy sądowi. Urzędnicy ci korzystali - pod kontrolą prokuratorów marynarki bądź ich zastępców z pomocy władz wojskowych lub policji. Legislator dopuszczał możliwość wszczęcia śledztwa 1) w oparciu o bezpośrednie oskarżenie władz floty i doniesienia dowódców różnych szczebli; 2) na podstawie meldunków policji, czynowników, urzędów i prokuratorów marynarki; 3) z oskarżenia i skarg osób prywatnych, jak również 4) po doprowadzeniu winnego złamania prawa do organów ścigania ${ }^{18}$. W ramach sądów wojenno-morskich funkcjonowały również kancelarie, w których byli zatrudnieni - jak wynika z zaprezentowanych wyżej etatów - sekretarze wraz z pomocnikami. Do zakresu ich powinności wchodziło prowadzenie korespondencji oraz wszelkiego rodzaju prace biurowe ${ }^{19}$.

Główny Morski Sąd Wojenny (ros. Gławnyj wojenno-morskij sud). Instytucja ta pełniła rolę najwyższego sądu kasacyjnego floty, którego odpowiednikiem armijnym stał się Główny Sąd Wojskowy. Natomiast powszechny wymiar sprawiedliwości uzyskał analogiczną agendę w postaci dwóch departamentów kasacyjnych Senatu. Głównemu Morskiemu Sądowi Wojennemu podlegały wszystkie sądy wojenno-morskie marynarki, z wyjątkiem identycznej instytucji działającej w porcie w Nikołajewie nad Amurem, podporządkowanej syberyjskiej filii Głównego Sądu Wojskowego sił lądowych ${ }^{20}$. Jak wiadomo, ten ostatni urząd nie został jednak utworzony i tym samym krąg oddziaływania najwyższego sądu kasacyjnego objął także sąd nikołajewski ${ }^{21}$.

Zgodnie z etatem z 22 czerwca 1867 r. w Głównym Morskim Sądzie Wojennym zasiadali mianowani bezpośrednio przez cara: przewodniczący (admirał bądź generał), dwóch sztabsoficerów z nominacji głównego komendanta portu, jeden stały członek sądu wojenno-morskiego desygnowany przez jego prezesa, główny prokurator marynarki z zastępcą, referent $\mathrm{z}$ dwoma pomocnikami (jednym młodszym, a drugim starszym) oraz dwóch kandydatów na stanowiska sędziowskie w resorcie morskim.

\footnotetext{
18 Ibidem, s. 5, 30-31, 65, 73, 110.

19 Ibidem, s. 2.

$20 \quad$ Ibidem, s. 1.

21 Г. И. Загорский, Военно-судебная реформа 1867 года как реализация идеей судебной реформы 1864 г. в деятельности органов военной юстищии, „Вестник военного права” 2016, nr 3, s. 50.
} 
Utrzymanie ich wszystkich, razem z sumami asygnowanymi na najem pisarzy i stróżów, zakup materiałów kancelaryjnych, remont umeblowania i oświetlenie, pochłaniało rokrocznie kwotę 64090 rubli $^{22}$. Główny Morski Sąd Wojenny posiadał stałą siedzibę w Sankt Petersburgu. Niemniej jednak w portach położonych w znacznej odległości od stolicy, gdzie rezydowali główni komendanci, w szczególnie ważnych przypadkach złamania dyscypliny, wymagających niezwłocznego ukarania delikwenta, ustawodawca dopuszczał możliwość - za zgodą cesarza - powołania specjalnego urzędu o takim samym wachlarzu kompetencji, jaki przewidziano dla najwyższego sądu kasacyjnego ${ }^{23}$.

Podczas gdy sądy załogowe i wojenno-morskie zajmowały się rozpatrywaniem casusów $\mathrm{z}$ merytorycznego punktu widzenia, to najważniejsze zadanie Głównego Morskiego Sądu Wojennego koncentrowało się na rozpatrywaniu: kasacyjnych oraz prywatnych skarg i protestów na wyroki sądów wojenno-okręgowych, wniosków odwoławczych od werdyktów sądów załogowych, próśb i wniosków o rewizję werdyktu z powodu ujawnienia nowych okoliczności, które uzyskały moc prawną, jak i spraw o nałożenie kar dyscyplinarnych na osoby zatrudnione $\mathrm{w}$ resorcie sądowym floty. Ponadto organ ten zobligowano do konsultowania zagadnień prawodawczych dotyczących całego pionu sądowniczego marynarki oraz systemu kar i grzywien ${ }^{24}$. Zatem obdarzono go prerogatywami do uściślania i modyfikacji obowiązującego w marynarce ustawodawstwa karnego. Opinie sędziów Głównego Morskiego Sądu Wojennego, które uzyskały cesarską aprobatę, stawały się prawem. Rzecz jasna najwyższy sąd kasacyjny floty musiał dodatkowo kontrolować, czy podległe mu instytucje wymiaru sprawiedliwości stosowały ustawy w jednolity sposób.

Regulamin sądowy z 1867 r. przewidywał powołanie organów prokuratorskich. Chociaż instytucja ta była już znana w Rosji od czasów Piotra I, to do chwili reformy wymiaru sprawiedliwości spełniała zarówno w marynarce wojennej, jak i w wojskach lądowych funkcje administracyjne oraz kontrolne. Teraz zakres obowiązków oraz organizacja prokuratury miały ulec radykalnej zmianie. Urzędy prokuratorów, wraz z zastępcami, pojawiły się przy każdym sądzie wojenno-morskim. Agendy te grupowały - powołując się na etat sądów w Sankt Petersburgu i Kronsztadzie z 22 czerwca 1867 r. - prokuratora z jednym lub dwoma zastępcami, sekretarza i pisarza.

22 ПСЗРИ (II), t. 42, otd. 2, nr 44734, s. 520. Etat Głównego Morskiego Sądu Wojennego opublikowany w 1902 r. przewidywał już czterech, a nie trzech członków. Wszyscy powinni posiadać rangi admirałów lub wiceadmirałów, względnie generałów albo generał lejtnantów; zob. СMП, kn. 1, s. 66.

23 Военно-морской судебный устав..., s. 9-10.

24 Ibidem, s. 137. 
Każdego roku państwo przeznaczało na ich działalność, razem z wydatkami biurowymi, sumy rzędu 7855 rubli (w stolicy) i 10275 rubli (w Kronsztadzie ${ }^{25}$. Natomiast - jak już zasugerowano powyżej - w ramach Głównego Morskiego Sądu Wojennego działał główny prokurator floty z zastępcą czuwającym nad prawidłowym funkcjonowaniem jego pionu kancelaryjnego. Prokurator główny i prokuratorzy wojenno-morscy wraz z zastępcami mogli być nominowani z grona urzędników wojskowych i cywilnych posiadających wykształcenie prawnicze i parających się praktyką sądową, z tym, że tego pierwszego wyznaczał generał-admirał na wniosek ministra spraw morskich, a tych drugich - na wniosek prokuratora głównego minister spraw morskich ${ }^{26}$. Do obowiązków prokuratorów należało wykonywanie nadzoru nad przestrzeganiem ustaw podczas rozpraw sądowych, pełnienie funkcji oskarżycielskich oraz kontrolowanie przebiegu śledztw wstępnych prowadzonych przez sędziów śledczych i komisje specjalne. W wypadku stwierdzenia naruszenia litery prawa lub jakichkolwiek uchybień proceduralnych, niezależnie od wyroku zasądzonego przez sąd wojenno-morski, prokurator informował o swych spostrzeżeniach - stosownie do wagi uchybienia - albo przewodniczącego sądu, albo głównego prokuratora marynarki. Ten ostatni, za zgodą generał-admirała i poprzez ministra spraw morskich, podejmował decyzję o skierowaniu sprawy do Głównego Morskiego Sądu Wojennego ${ }^{27}$.

Główny prokurator marynarki, z urzędu, stał na czele Głównego Wojenno-Morskiego Zarządu Sądowego (ros. Gławnoje wojenno-morskoje sudnoje uprawlienije). Struktura ta, działająca w ramach Ministerstwa Morskiego, na bazie zlikwidowanego Zarządu Floty generał-audytora, nie dysponowała żadnymi uprawnieniami do orzekania o winie czy niewinności oskarżonych oraz nadzoru nad systemem wymiaru sprawiedliwości ${ }^{28}$. Zawiadywała działem kancelaryjnym Głównego Morskiego Sądu Wojennego, a więc przygotowywała różnego rodzaju zestawienia statystyczne na temat działalności pionu sądowego floty, które przekazywała następnie ministrowi spraw morskich lub za jego pośrednictwem carowi. Ponadto zajmowała się sprawami przestępstw, jakich dopuścili się oficerowie i urzędnicy marynarki oraz prowadziła korespondencję co do werdyktów sądów, które podlegały zatwierdzeniu przez imperatora. Odpowiadała też za organizację więzień i innych punktów odosobnienia resortu morskiego, jak również za utrzymanie materialne skazańców. Jednocześnie napływały do niej wszystkie kwestie wiążące się z: wycofywaniem zasądzonych przez składy orzekające grzywien

\footnotetext{
25 ПСЗРИ (II), t. 42, otd. 2, nr 44734, s. 520.

Военно-морской судебный устав..., s. 21-22.

27 Ibidem, s. 11-12, 25, 33, 73.

28 ПСЗРИ (II), t. 42, otd. 1, nr 44734, s. 966.
} 
i innych sankcji pieniężnych, katastrofami oraz wypadkami uszkodzeń okrętów wojennych oraz statków handlowych, jak i utratą znajdującego się na pokładach sprzętu i w ogóle państwowego mienia ruchomego. W orbitę zainteresowań rzeczonej agendy wchodziły też zagadnienia legislacyjne dotyczące zasad stosowania ustaw w zakresie odpowiedzialności karnej i dyscyplinarnej, nadzór nad sprawami personalnymi całej marynarki oraz placówkami naukowo-edukacyjnymi zorientowanymi na kształcenie prawników morskiego segmentu sił zbrojnych. Według ogłoszonych 3 czerwca 1885 r. regulaminach o zarządzie resortem morskim i etatów Ministerstwa Morskiego i zarządów portowych, które weszły w życie 1 stycznia $1886 \mathrm{r}$. personel Głównego Wojenno-Morskiego Zarządu Sądowego tworzyli: prokurator główny wraz z zastępcą, czterech referentów (dwóch starszych i dwóch młodszych), dwóch oberaudytorów (czyli urzędników wojskowo-sądowych), młodszy urzędnik oraz nieokreślona liczba pisarzy. W skali roku skarb carski przeznaczał na pensje dla nich, jak również: zakup materiałów biurowych i oświetleniowych, utrzymanie stróżów, umeblowanie oraz pomniejsze opłaty 26100 rubli $^{29}$.

Scharakteryzowany powyżej trójinstancyjny model Temidy, przewidziany dla okresu pokojowego, miał z pewnymi wyjątkami obowiązywać także w czasie konfliktu zbrojnego. Pewne różnice organizacyjne i proceduralne wynikały z możliwości pojawienia się nadzwyczajnych sytuacji, w jakich mogły znaleźć się sądy marynarki w warunkach bojowych, gdyby nastąpiło przerwanie łączności z instytucjami brzegowymi oraz z powodu konieczności przyspieszenia procedur na rzecz szybszego doprowadzenia rozpatrywanych spraw do końca. Kodeks sądowy floty z 15 maja 1867 r. stwierdzał, że: „Sąd w czasie wojny na brzegu odbywa się na podstawach, określonych w wydanym tego samego dnia Regulaminie wojskowo-sądowym resortu lądowego podczas wojny"30. Regulacja ta przewidywała powołanie przy Sztabie Polowym Armii - Polowego Głównego Sądu Wojskowego, a w razie potrzeby także tymczasowych sądów polowych przy korpusach bądź innych oddziałach, które operowały w oddaleniu od zasadniczych sił armii. Identyczne instytucje, złożone $\mathrm{z}$ trzech członków (dwóch sztabsoficerów i jednego sędziego sądu wojenno-morskiego) i jednego prokuratora floty, mogły również powstawać $\mathrm{w}$ razie zaistnienia jakichkolwiek nadzwyczajnych okoliczności ${ }^{31}$.

29 CMП, kn. 1, s. 5, 80. Pochodzący z 18 VI 1867 r. regulamin o zarządzie resortem morskim ani słowem nie wspominał o Głównym Wojenno-Morskim Zarządzie Sądowym; zob. ПСЗРИ (II), t. 42, otd. 1, nr 44714, s. 914-925.

30 Военно-морской судебный устав..., s. 177.

31 Свод военных постановлений 1869 года (СВП), сz. 6, kn. 24: Устав Военно-Судебньй, Санкт-Петербург 1879, s. 16, 235. 
Po przeprowadzeniu śledztwa wstępnego prokurator był zobligowany do przedstawienia sądowi polowemu aktu oskarżenia w ciągu dwóch dni, jakie upłynęły od momentu uzyskania od dowództwa informacji o dokonaniu przestępstwa. Ustawa pozostawiała składom orzekającym trzy doby na ogłoszenie wyroku, dopuszczając możliwość składania skarg i protestów kasacyjnych, ale musiały one wpłynąć maksymalnie w ciągu dwóch dni. Werdykty - w tym te przewidujące karę śmierci - które uzyskały moc prawną, trafiały podczas wojny do głównych komendantów portów. Ci ostatni, podobnie jak komendanci portów drugiej kategorii i inni dowódcy marynarki wojennej działający samodzielnie, w wyjątkowych sytuacjach, gdy zaistniała potrzeba natychmiastowego wykonania wyroku, posiadali uprawnienia do ostatecznego jego zatwierdzenia, nie nadając sprawie biegu w trybie kasacyjnym, czyli nie przesyłając jej do Polowego Głównego Sądu Wojskowego ${ }^{32}$.

Ogólny nadzór nad wszystkimi sądami marynarki wojennej i instytucjami prokuratury należał do ministra spraw morskich, który bezpośrednio podlegał cesarzowi ${ }^{33}$. Posiadał on prerogatywy do przeprowadzania w organach Temidy kontroli (rewizji) tak osobiście, jak i za pośrednictwem mianowanych przez siebie urzędników sądowych zatrudnionych w Głównym Wojenno-Morskim Zarządzie Sądowym. Rzecz jasna podczas takich inspekcji minister bądź wyznaczony czynownik mógł nakładać kary na sprawców wykrytych nieprawidłowości w postaci nagan i upomnien ${ }^{34}$.

Zaprowadzona w marynarce, w oparciu o regulamin z 15 maja 1867 r., nowa struktura wymiaru sprawiedliwości opierała się na kanonach niezależności sądów od organów administracyjnych. Norma ta została zabezpieczona przez specjalną procedurę mianowania sędziów, których nie można było dowolnie usuwać ze stanowisk i zastępować innymi kandydatami. Nominacje, zwalnianie i przenoszenie na inne stanowiska służbowe przewodniczącego i członków Głównego Morskiego Sądu Wojennego należały do wyłącznych uprawnień imperatora. Wyznaczanie prezesów i sędziów sądów wojenno-morskich oraz sędziów śledczych legislator uzależnił od decyzji ministra spraw morskich, choć ich mianowanie na stanowisko należało do prerogatyw cara. Natomiast ich dymisje, które doszły do skutku nie na ich osobistą prośbę, mogły mieć miejsce tylko na podstawie uchwały Głównego

\footnotetext{
32 Ibidem, s. 93-95, 241-242.

33 Военно-морской судебный устав..., s. 25. Głównym zwierzchnikiem floty wojennej i Ministerstwa Morskiego był wybierany przez cara generał-admirał, zajmujący jednocześnie stanowisko przewodniczącego Rady Admiralicji. Podlegał mu urzędnik z tytułem „zarządzający Ministerstwem Morskim”, kierujący resortem morskim na prawach ministra i piastujący jednocześnie funkcję wiceprzewodniczącego Rady Admiralicji; zob. ПСЗРИ (II), t. 42, otd. 1, nr 44714, s. 914-915; СMП, kn. 1, s. 2-3.
}

34 Военно-морской судебный устав..., s. 25-27. 
Morskiego Sądu Wojennego ${ }^{35}$. Procedura pociągania sędziów do odpowiedzialności karnej i dyscyplinarnej stała się bardziej skomplikowana, co stanowiło dodatkowy środek ochronny przed ingerencją administracji. Prezesi i członkowie sądów wojenno-morskich podlegali słownym oraz pisemnym upomnieniom i naganom, które można było ogłaszać także w urzędach sądowych. Jednocześnie dopuszczano możliwość pozbawienia ich posady oraz wydalenia ze służby. Prawo do karania członków składów orzekających przysługiwało Głównemu Morskiemu Sądowi Wojennemu i zarządzającemu Ministerstwem Morskim ${ }^{36}$. Ustawodawca zadbał ponadto o odpowiednie wykształcenie fachowe stałych sędziów sądów wojenno-morskich i najwyższej instancji kasacyjnej, którzy odtąd mogli się rekrutować jedynie spośród absolwentów studiów prawniczych. Podobny wymóg postawiono śledczym, sekretarzom i referentom zatrudnionym $\mathrm{w}$ pionie sądowym ${ }^{37}$. Podniesiono ponadto pobory sędziom, dzięki czemu zostały ograniczone możliwości nacisków na nich ze strony administracji i osób prywatnych. Tym sam zwiększyła się bezstronność, a w konsekwencji jakość wykonywanej przez nich pracy. Większe wynagrodzenie trafiło również do prokuratorów oraz pozostałych pracowników działu odpowiadającego za wymiar sprawiedliwości. Spisy etatowe z 22 czerwca 1867 r. ujawniają, że prezes i członkowie Głównego Morskiego Sądu Wojennego zarabiali, uwzględniając pensję oraz tzw. sumy stołowe (na racje żywnościowe) i kwaterunkowe (na wynajem mieszkań), 7000 rubli rocznie, podczas gdy przewodniczący sądów wojenno-morskich w Sankt Petersburgu i Kronsztadzie 5250, a sędziowie po 3000 rubli na rok $^{38}$.

Nowością było zerwanie z inkwizycyjnymi kanonami prowadzenia procesu karnego i przejście do modelu rozpraw z udziałem stron. Karne przewody sądowe oparte na procedurze jawnej, publicznej i ustnej zostały podzielone na dwie części, mianowicie śledztwo wstępne, należące do powinności sędziego śledczego, a więc urzędu nieznanego dotychczas w Rosji oraz właściwy sąd. Oprócz tego instytucje wymiaru sprawiedliwości pozbawiono funkcji oskarżycielskich, przeniesionych teraz na prokuratorów i ich zastępców. Gwarantowało to skuteczną realizację w sądownictwie floty zasady domniemania niewinności podsądnych. Nowy kodeks gwarantował tym ostatnim prawo do posiadania obrońców, którzy zaczęli korzystać z takiego samego wachlarza uprawnień jak nadzór prokuratorski. Równocześnie

\footnotetext{
35 Ibidem, s. 22-23.

36 Ibidem, s. 26-27.

37 Ibidem, s. 21, 30.

38 ПСЗРИ (II), t. 42, otd. 2, nr 44734, s. 520. Powyższe stawki wynagrodzeń utrzymano w wydanej 1 IV 1874 r. drugiej edycji Wojenno-morskiego regulaminu sq̨dowego; zob. ПСЗРИ (II), t. 49, otd. 3, załączniki do nr 53333, s. 74.
} 
nastąpiło zerwanie z pryncypiami formalnej teorii dowodowej, która zdominowała rozprawy karne w marynarce wojennej przed reformą $1867 \mathrm{r}$. Od tej pory sędziowie, decydując o losie oskarżonych, powinni stosować założenia swobodnej oceny dowodów przedstawionych w toku przewodu sądowego, co oznaczało, że werdykty miały się opierać na ich wewnętrznych przekonaniach, wynikających z okoliczności rozpatrywanych spraw ujawnionych podczas procesu. Do nadrzędnych obowiązków sędziego należało uniewinnienie lub skazanie winnego. Tym samym doszło do likwidacji instytucji pozostawania podsądnego w stanie podejrzenia. Orzeczenia końcowe sądów marynarki, które zawsze były ciałami kolegialnymi, uzyskały charakter niezmienności, a Główny Morski Sąd Wojenny, jako najwyższy sąd kasacyjny, obarczono powinnością czuwania na zachowaniem przez organa Temidy niższych instancji zasad i obyczajów sądowych ${ }^{39}$.

\section{Schemat 1. Organizacja systemu wymiaru sprawiedliwości rosyjskiej marynarki wojennej po $1867 \mathrm{r}$.}

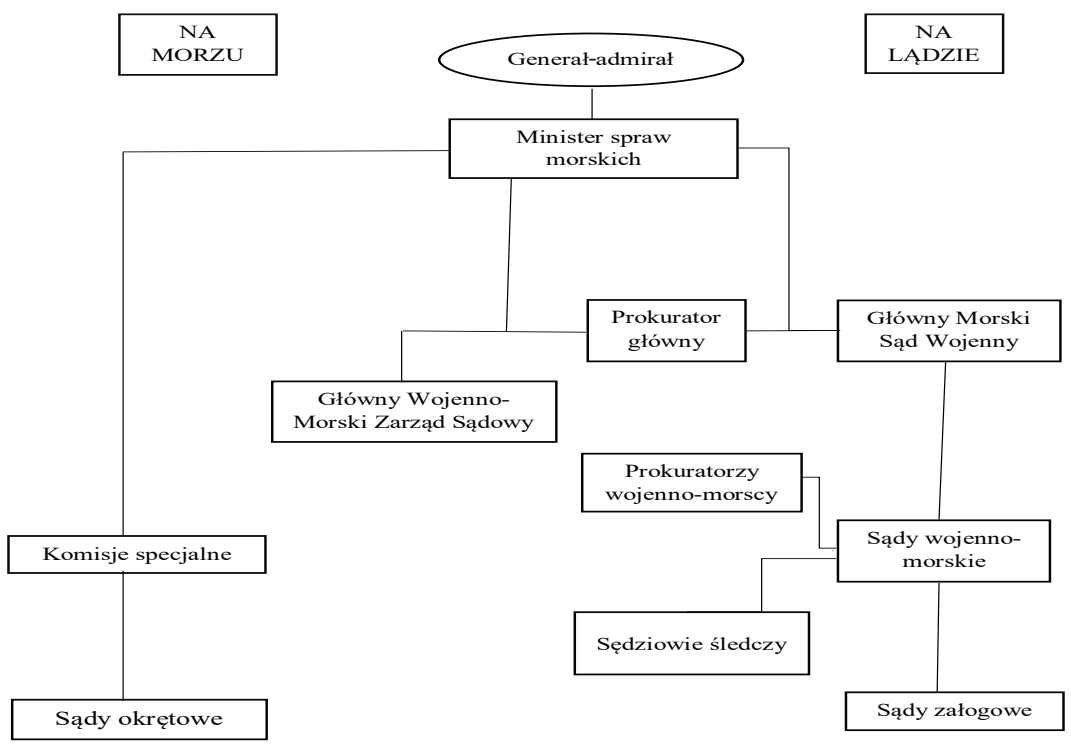

Źródło: opracowanie własne.

Wojenno-morski regulamin sądowy wprowadził wyraźne rozgraniczenie podsądności spraw karnych na okres pokoju i lata wojny. W czasach pokojowych zasięgiem działania agend wymiaru sprawiedliwości floty objęto wszystkich bez wyjątku, pełniących w niej służbę czynną i przebywających

39 Военно-морской судебный устав..., s. 40-59, 61-97, 99-135, 137-150. 
na urlopach: admirałów, generałów, sztab- i oberoficerów, podoficerów, marynarzy, urzędników rangowych oraz pracowników cywilnych za niezgodne z literą prawa czyny, ale tylko te stanowiące bezpośrednie naruszenie obowiązków i dyscypliny służbowej. Podczas konfliktu zbrojnego krąg podmiotów podlegających powoływanym wówczas polowym organom wymiaru sprawiedliwości znacznie się poszerzał. Nadano im bowiem kompetencje do sądzenia wszystkich osób służących w jednostkach bojowych, a więc również urzędników i pracowników intendentury, czyli dostawców, kupców, woźniców itp. oraz dodatkowo cywilów zamieszkujących w portach, w których ogłoszono stan wojenny, jak i mieszkańców obszarów nieprzyjacielskich (w przypadku flot nadmorskich) zajętych przez oddziały carskie. W orbitę podsądności organów sprawiedliwości marynarki wchodzili także jeńcy wojenni, za dopuszczenie się niezgodnych z prawem czynów, jeszcze przed ich przekazaniem resortom cywilnym ${ }^{40}$. Podsądność sądów floty nie obejmowała: a) czynów karalnych wymierzonych w wiarę prawosławną i naruszających przepisy cerkiewne oraz działań niezgodnych z prawem, jakich dopuścili się duchowni; b) niektórych przestępstw państwowych; c) wykroczeń służbowych popełnionych przez pracowników pionu sądowego marynarki; d) czynów przestępczych odnoszących się do różnych działów zarządu administracyjnego; e) spraw karnych o mieszanej, wojenno-morskiej i cywilnej podległości sądowej i f) wypadków pogwałcenia przepisów o prasie ${ }^{41}$. W przypadku pojawienia się sporów pomiędzy władzami floty a sądami duchownymi lub cywilnymi co do podsądności konkretnej sprawy ostateczną decyzję podejmowało wspólne zgromadzenie departamentów kasacyjnych Senatu. Zatargi tego rodzaju z organami publicznego zarządu administracyjnego lub zatrudnionymi w nich osobami rozstrzygały cywilne sądy okręgowe ${ }^{42}$.

Ustrój sądownictwa marynarki wojennej wprowadzony w 1867 r. nie przewidywał - w przeciwieństwie do rozwiązań wprowadzonych trzy lata wcześniej dla powszechnego wymiaru sprawiedliwości - możliwości apelacji od wyroków sądów niższego szczebla do wyższych instancji. Zdaniem Aleksandra Pilipienki wynikało to $\mathrm{z}$ faktu uczestnictwa w procesach przed sądami wojenno-morskimi, obok sędziów stałych posiadających studia prawnicze, członków tymczasowych - jak wiadomo - dobieranych z grona oficerów liniowych, którzy z powodu braku teoretycznej wiedzy

40 Ibidem, s. 37, 177; Устав Военно-Судебныци..., s. 236-237.

41 Военно-морской судебный устав..., s. 157. Dekret carski z 9 II 1870 r. rozszerzył działanie Wojenno-morskiego regulaminu sądowego na wszystkich urzędników zatrudnionych $\mathrm{w}$ agendach resortu morskiego na zasadach pracowników najemnych; zob. ПСЗРИ (II), t. 45 , otd. 1, nr 48014, s. 151.

42 Военно-морской судебный устав..., s. 39. 
jurystycznej i doświadczeń wynikających z pracy w pionie sądowym stanowili niefachowy element składów orzekających, reprezentujący ogół społeczności wojskowej. Ich rola w wypracowywaniu wyroków była taka sama jak zawodowych sędziów. Ponieważ według ustaw z 1864 r. sentencje końcowe zasądzone $\mathrm{w}$ takim trybie nie podlegały apelacji, to ustawodawca przewidywał rewizje wyroków sądów wojenno-morskich jedynie w drodze kasacji albo na podstawie carskiego rozkazu ${ }^{43}$. Wojenno-morski regulamin sqdowy sankcjonował skargi oraz protesty kasacyjne w: 1) wypadku jawnego naruszenia właściwego sensu ustawy i nieprawidłowej jej interpretacji podczas ustalania tak rodzaju przestępstwa, jak i doboru sankcji karnej; 2) razie pogwałcenia zwyczajów i form sądowych na tyle ważnych, że bez ich przestrzegania nie byłoby możliwe uznanie zasądzonego wyroku za decyzję sądu oraz 3) przypadku przekroczenia zakresu władzy nadanej ustawowo sądowi wojenno-okręgowemu ${ }^{44}$. W stosunku do wszystkich kierowanych do Głównego Morskiego Sądu Wojennego skarg i protestów kasacyjnych główny prokurator floty występował z pisemnym wnioskiem wstępnym, w którym wyłuszczał okoliczności danej sprawy podlegające rozstrzygnięciu w trybie kasacyjnym, wymieniając jednocześnie odnoszące się do niej regulacje prawne. Jeśli sędziowie uznali, że doszło tylko do nieprawidłowego zastosowania ustaw, to po uchyleniu wyroku sami mogli rozstrzygnąć sprawę, skazując lub uniewinniając podsądnego. W pozostałych wypadkach, po anulowaniu werdyktu, przekazywali sprawę albo do organu sądowego, który uprzednio się nią zajmował, albo do innego sądu wojenno-morskiego w celu wszczęcia nowego postępowania, poczynając od tych czynności, które posłużyły za powód do kasacji. Termin składania zaskarżeń do najwyższego sądu kasacyjnego marynarki w okresie pokoju wynosił siedem dni. Podczas wojny - jak już zasygnalizowano - ulegał on redukcji do zaledwie dwóch dób ${ }^{45}$.

Poruszając problem procedur uchylania sentencji końcowych wydanych przez instytucje Temidy floty należy wspomnieć o tym, że cały pion sądowy tego komponentu rosyjskich sił zbrojnych nie podlegał kompetencjom Senatu, który był najwyższą instytucją kasacyjną jedynie dla sądów powszechnych. W efekcie, jeśli pojawiła się potrzeba przeprowadzenia kasacji wyroku wydanego w stosunku do marynarza przez sędziego pokoju bądź sąd okręgowy, czyli cywilne organa wymiaru sprawiedliwości, to minister spraw morskich musiał się zwrócić do Senatu z odpowiednią petycją w tej

43 А.Н. Пилипенко, Военно-морское судебное ведомство в судебной системе Российской империи в конце XIX в., „Вестник Южно-Уральского государственного университета. серия: Социально-гуманитарные науки" 2014, t. 14, nr 2, s. 50.

44 Военно-морской судебный устав.., s. 135.

45 Ibidem, s. 133, 138-139. 
sprawie. Co warte podkreślenia, Główny Morski Sąd Wojenny - podejmując decyzję o anulowaniu orzeczenia sądu niższej instancji - mógł samodzielnie interpretować przepisy prawne, nie zwracając uwagi na decyzje i praktyki Senatu ${ }^{46}$.

Chociaż kodeks z 15 maja 1867 r. wprowadzał do Temidy marynarki nowoczesne, odpowiadające standardom zachodnioeuropejskim - zwłaszcza francuskim - rozwiązania strukturalne, to niektórych z nich, w przeciwieństwie do powszechnego systemu wymiaru sprawiedliwości, nie udało się całkowicie wprowadzić w życie. Została zachowana zależność organów sądowych od administracji, reprezentowanej we flocie przez dowódców wyższego szczebla. Jak wiadomo, cały pion sądowy morskiego komponentu sił zbrojnych podlegał generał-admirałowi, czyli oficerowi mianowanemu przez cesarza i ponoszącemu przed nim odpowiedzialność za swe decyzje. Na poziomie sądów załogowych ogromne prerogatywy w przedmiocie wymierzania sprawiedliwości uzyskali naczelnicy (dowódcy) wojskowi. To właśnie od ich opinii i zgody zależało wszczęcie ścigania sądowego w razie popełnienia przestępstwa lub wykroczenia przez służących we flocie. Równocześnie ukierunkowywali oni dalszy bieg spraw, tzn. decydowali o tym, czy wystarczy ukarać winnego w trybie dyscyplinarnym, czy przekazać go - odpowiednio do wagi czynu karalnego, jakiego się dopuścił sądowi załogowemu lub wojenno-morskiemu. Akta sprawy zainicjowanej przez prokuraturę trafiały do bezpośredniego zwierzchnika oskarżonego, od którego zależało podjęcie decyzji o ich odesłaniu do odpowiedniej instytucji Temidy ${ }^{47}$. Działania władz niejednokrotnie uderzały także w pryncypia niezawisłości i nieusuwalności sędziów. W działalności sądów morskich nadal dość mocno były uwypuklone motywy społeczne. Sentencje końcowe, jakie zapadły w sprawach z udziałem: a) oficerów, urzędników, szlachty i duchownych skazanych na karę pozbawienia wszystkich praw stanu lub uprawnień i przywilejów specjalnych, ewentualnie degradację do stopnia marynarza i szeregowca oraz b) osób ukaranych odebraniem im orderów bądź odznaczeń wręczonych osobiście przez imperatora lub na noszenie których monarcha wyraził zgodę, nawet jeśli nabrały mocy prawnej, to przed wprowadzeniem ich $\mathrm{w}$ życie musiały być przedstawione ministrowi spraw morskich, który poprzez głównodowodzącego generał-admirała kierował je do cara w celu zatwierdzenia albo odrzucenia ${ }^{48}$. Jednocześnie legislator zupełnie nie przewidział dla sądownictwa marynarki instytucji sędziów przysięgłych. Ponadto nie wszystkim oskarżonym zagwarantowano prawo do obrony.

\footnotetext{
46 А.Н. Пилипенко, Военно-морское судебное ведомство..., s. 50.

47 Военно-морской судебный устав..., s. 32-33, 37-38, 63, 94.

48 Ibidem, s. 148-149.
} 
Chociaż rząd starał się oprzeć strukturę wymiaru sprawiedliwości floty na takich samych fundamentach organizacyjno-proceduralnych, jakie przewidziano dla sił lądowych i - co ważniejsze - sądownictwa powszechnego, to przeprowadzenie pełnej unifikacji okazało się niemożliwe. Tak naprawdę jedynym ogniwem spajającym te trzy działy była osoba monarchy, występującego w roli najwyższego ustawodawcy i sędziego. Niemniej faktyczny wpływ cara na wykonywanie sądownictwa sprowadzał się do konfirmowania wyroków, jakie sądy wydawały w niektórych kategoriach spraw oraz rozpatrywania próśb o uniewinnienie skazańców, względnie złagodzenie ciążących na nich kar. Od samego początku system Temidy marynarki stanowił pion niezależny, i to nie tylko od sądów cywilnych, ale również armijnych, pomimo tego, że teksty kodeksów sądowych armii i floty, jakie pojawiły się w maju 1867 r., różniły się między sobą tylko nieistotnymi detalami natury leksykalnej. Okoliczność ta nie może dziwić, ponieważ stanowiły one rezultat połączonych wysiłków reprezentantów obu wspomnianych resortów ${ }^{49}$. Dlatego początkowo struktura sądownictwa marynarki i sił lądowych była praktycznie identyczna, co jednak z czasem uległo zmianie, przede wszystkim ze względu na konieczność dostosowywania dawnych i opracowywania nowych regulacji, z uwzględnieniem osobliwości służby morskiej.

Wojenno-morski regulamin sądowy nie zawierał przepisów o zasadach wykonywania sądownictwa podczas żeglugi oraz prowadzenia spraw o spowodowanie katastrof i uszkodzeń okrętów. Obie te kwestie doczekały się realizacji dopiero 6 kwietnia 1870 r. Tego dnia Aleksander II podpisał Regulamin o prowadzeniu sądu w czasie rejsu. Regulacja ta, podzielona na 44 punkty, uszeregowane w trzech rozdziałach, zezwalała na powoływanie na każdym okręcie odbywającym rejs zagraniczny oraz na jednostkach pływających zaliczonych do pierwszych dwóch klas, które operowały na wodach wewnętrznych, tzw. sądów okrętowych (ros. karabiel'nyje sudy), stanowiących odpowiedniki funkcjonujących na lądzie sądów załogowych. Tego rodzaju organów nie można było tworzyć na pokładach okrętów trzeciej i czwartej klasy, wyekspediowanych na wody wewnętrzne. Niemniej, jeśli poruszały się one w składzie eskadry lub innego zespołu, to ustawodawca dopuszczał możliwość ustanowienia - według uznania dowódcy takiego zgrupowania - jednego sądu okrętowego dla dwóch lub więcej jednostek pływających bądź odsyłania spraw do tego rodzaju instytucji, na stałe funkcjonującej na okręcie pierwszej albo drugiej klasy. Jeśli jednostki pływające trzeciej albo czwartej klasy odbywały samotny rejs po wodach wewnętrznych, to wyjaśnienie wszystkich stwierdzonych czynów karalnych powinno zostać odłożone do momentu ich powrotu do portu, z przekazaniem

49 А.Н. Пилипенко, Военно-морское судебное ведомство..., s. 50-51. 
casusów do właściwego sądu załogowego. Niezależnie od tego kapitanowie, jeśli stwierdzili, że obecność sprawcy na pokładzie zagraża bezpieczeństwu załogi, a zastosowana uprzednio wobec niego sankcja dyscyplinarna nie odniosła pożądanego skutku, mogli oddelegować delikwenta na pierwszy napotkany na szlaku okręt wojenny, względnie skierować go do etapu, po czym do powinności głównego zwierzchnika eskadry należało odstawienie oskarżonego do instytucji Temidy zainstalowanej na brzegu ${ }^{50}$.

Rozprawy przed sądami okrętowymi dochodziły do skutku wyłącznie na jednostkach, na których dokonano przestępstwa. Jedynie w eskadrach i innego typu zespołach, stosownie do decyzji ich dowódców, legislator sankcjonował przewody sądowe na każdym, wchodzącym w ich skład okręcie. Regulamin o prowadzeniu sądu w czasie rejsu nadawał dowódcy okrętu, jaki wyszedł w morze, uprawnienia i obowiązki przynależne w lądowych sądach okręgowych zwierzchnikom załóg. Z kolei naczelny dowódca eskadry bądź innego zespołu uzyskiwał prerogatywy właściwe głównym komendantom portów. Na odbywających samotne wojaże jednostkach pływających adekwatny wachlarz kompetencji przysługiwał kapitanowi okrętu, na pokładzie którego powołano sąd ${ }^{51}$. Przewodniczących, członków (sędziów) i sekretarzy sądów okrętowych mianowano na czas trwania kampanii wojennej. W przypadku rejsu zagranicznego, trwającego ponad pół roku, prezesa - po upływie czterech, a sędziów - trzech miesięcy zastępowali inni oficerowie. Przewidziano także możliwość wymiany całego składu orzekającego, względnie tylko jego poszczególnych członków, jak również ich odwołania na mocy rozkazu dowódcy. Nawet jeśli kapitan okrętu nie zaaprobował werdyktu sądowego, to ustawowo musiał go zatwierdzić, ale z prawem do wyznaczenia takiej kary, której nałożenie nie przekraczało prerogatyw sądu załogowego orzekającego na lądzie. Kiedy okręt operował w składzie eskadry albo innego zespołu, to regulamin obligował jej dowódcę do przedstawiania akt sprawy - z własną opinią - głównodowodzącemu eskadry. Ten ostatni także dokonywał ostatecznej konfirmacji sentencji końcowej, nie wykraczając jednak poza prerogatywy przyznane dowódcy jednostki pływającej odbywającej samodzielny rejs ${ }^{52}$. Zatwierdzone wyroki nie podlegały zaskarżeniu przez podsądnych i były bezzwłocznie wprowadzane w życie. Ustawodawca tolerował jedynie odwołania składane przez osoby trzecie, które poniosły szkodę w wyniku sprzecznej z prawem działalności skazanego. W tego typu wypadkach, zaraz po zawinięciu okrętu do portu, sprawę przekazywano

50 Положение о производствие суда во времия плавания, „Морской Сборник” 1870, t. 108, nr 5, официальный отдел, s. 23.

51 Ibidem, s. 23-24.

52 Ibidem, s. 25. 
do sądu wojenno-morskiego. Gestii sądów okrętowych podlegali nie tylko należący do załóg podoficerowie i marynarze, których na lądzie mogły sądzić sądy załogowe, ale również wszystkie inne, przebywające na pokładzie persony, niekorzystające ze specjalnych praw stanowych, służbowych lub nabytych $\mathrm{z}$ racji wykształcenia ${ }^{53}$.

Podczas żeglugi nie wchodziła w grę możliwość powoływania składów orzekających odpowiadających zakresem uprawnień lądowym sądom wojenno-morskim. Legislator przystał jednak na to, aby dowódcy okrętów, jakie wyruszyły w samodzielną wyprawę - według własnego uznania - ustanawiali specjalne komisje z zadaniem wstępnego przeanalizowania czynu podlegającego karze, której wymierzenie przekraczało uprawnienia sądu okrętowego. Tego typu agendom pozostawiono dwa dni na przeprowadzenie śledztwa i sporządzenie wniosku o jego wynikach wraz z wyznaczeniem sankcji karnej. Komisje specjalne mogły powstawać jedynie wtedy, gdy od skazania winowajcy zależało utrzymanie spokoju i dyscypliny na pokładzie. Grupowały one sześciu oficerów i przewodniczącego, wyłanianego z grona posiadaczy najwyższego stopnia oficerskiego. W sytuacji, gdy na okręcie przebywało tylko siedmiu oficerów, to wszyscy wchodzili w skład rzeczonego organu śledczego. Końcową opinię komisji, razem z dokumentacją, prezes przedstawiał dowódcy okrętu, który mógł ją zatwierdzić lub wydać orzeczenie, zupełnie nie licząc się z jej zdaniem. W razie braku jednomyślności stanowiska poszczególnych członków były wpisywane do dziennika komisji. Kapitanom okrętów przysługiwało prawo do nakładania na winnych dowolnych kar, rzecz jasna tylko tych przewidzianych w ustawach, łącznie z pozbawieniem ich życia. Co więcej, mogli oni złagodzić zasądzoną sankcję, a nawet ułaskawić sprawcę. O każdym wypadku skazania dowódca jednostki pływającej musiał składać raport zarządzającemu Ministerstwem Morskim. Niektóre sprawy rozpatrzone $\mathrm{w}$ powyższym trybie, po zawinięciu okrętu do któregoś z portów rosyjskich, podlegały rewizji w Głównym Morskim Sądzie Wojennym. Jeśli kapitan nie zdecydował się na wyznaczenie komisji śledczej, to przyjmując osobistą odpowiedzialność, sam - bez dochodzenia - mógł zadecydować o losie osoby podejrzanej o naruszenie litery prawa ${ }^{54}$.

O ogromnym zakresie prerogatyw sądowniczych dowódców jednostek pływających świadczy nadanie im uprawnień do karania wszystkich obecnych na pokładzie osób w przypadku zdrady w obliczu nieprzyjaciela, jawnej rebelii i nieposłuszeństwa bądź jakichkolwiek innych działań zagrażających bezpieczeństwu okrętu. Naturalnie regulamin obligował kapitanów do informowania o tego rodzaju przypadkach generał-admirała lub - w razie

\footnotetext{
53 Ibidem, s. 26.
}

54 Ibidem, s. 27-28. 
jego nieobecności - ministra spraw morskich ${ }^{55}$. Po zakończeniu rejsu zawsze desygnowano komisję pod kierownictwem flagmana, czyli oficera stojącego na czele floty lub innego zespołu okrętów, względnie najstarszego, przebywającego w porcie dowódcy. Oprócz niego wchodziło do niej trzechczterech kapitanów jednostek pływających. Cel komisji sprowadzał się do dokładnego przestudiowania sprawozdania z działalności kapitana, który sięgnął podczas rejsu po nadzwyczajne środki prawne. Instytucję tę upoważniono, jeśli zaszła potrzeba, do przesłuchiwania członków załóg. Po zakończeniu prac akta sprawy wędrowały do Głównego Wojenno-Morskiego Zarządu Sądowego w celu jej dalszego ukierunkowania. Jeśli analizowana sprawa trafiła do najwyższego sądu kasacyjnego floty, a ten orzekł, że ocena sytuacji dokonana przez dowódcę była błędna, co oznaczało przekroczenie kompetencji służbowych, to stawał on przed sądem $\mathrm{z}$ jednoczesną utratą zajmowanego stanowiska ${ }^{56}$.

W wersji Regulaminu o prowadzeniu sądu w czasie rejsu, pochodzącej z 1 kwietnia 1874 r., zamieszczono dodatkowy artykuł, na mocy którego zarządzający Ministerstwem Morskim, w oparciu o raport głównego prokuratora floty, mógł nominować na czas trwania żeglugi - w miarę zapotrzebowania - urzędników sądowych, oddając ich do dyspozycji głównodowodzących eskadr i innych zespołów oraz kapitanów okrętów. Owi czynownicy rekrutowali się z grona pracowników Głównego Wojenno-Morskiego Zarządu Sądowego lub oficerów będących absolwentami Akademii Wojskowo-Prawniczej, ale tylko pierwszej kategorii ${ }^{57}$. Pojawienie się w systemie Temidy cesarskiej marynarki wojennej sądów okrętowych, funkcjonujących podczas rejsów szkoleniowych oraz kampanii wojennych, stwarzało sprzyjające warunki do wykonywania sprawiedliwości nie tylko na właściwym terytorium Rosji, ale także na otwartych wodach oceanicznych i morskich, u brzegów innych krajów. Rzeczone instytucje stały się kolejnym elementem odróżniającym morskie struktury wymiaru sprawiedliwości od ich armijnych odpowiedników ${ }^{58}$.

\section{Koniec części I}

(bibliografia dla całości artykułu po części II)

\footnotetext{
55 Положение о производствие суда во времия плавания..., s. 28-29.

56 Ibidem, s. 29-30.

57 ПСЗРИ (II), t. 49, otd. 1, nr 53333, s. 571.

58 А.Н. Пилипенко, Военно-морское судебное ведомство..., s. 51.
} 


\section{STRESZCZENIE}

\section{Leszek Madej, Struktura i zasady funkcjonowania sądownictwa rosyjskiej floty wojennej w latach 1867-1914 (część 1)}

W 1867 r. została przeprowadzona reforma systemu wymiaru sprawiedliwości rosyjskiej marynarki wojennej, którą wzorowano na rozwiązaniach strukturalnych przyjętych w armii lądowej. Wprowadzała ona trójinstancyjny podział organów sądowych. Sądy załogowe i wojenno-morskie rozpatrywały sprawy pod względem merytorycznym, zaś do Głównego Morskiego Sądu Wojennego były kierowane skargi i protesty kasacyjne. Procesy sądowe odbywały się w trybie kolegialnym, jawnym i publicznym. Oskarżonym zagwarantowano prawo do obrony, a przewody sądowe oparto na procesie $z$ udziałem stron i swobodnej ocenie materiału dowodowego. Przy Głównym Morskim Sądzie Wojennym i sądach wojenno-morskich pojawiły się urzędy prokuratorskie, pełniące funkcje oskarżycielskie. Obowiązek prowadzenia dochodzeń spadał na sędziów śledczych. Podczas rejsów i kampanii wojennych działały sądy okrętowe i komisje specjalne, wyrokujące w oparciu o procedury, odmienne od tych obowiązujących w lądowych sądach morskich.

Słowa kluczowe: rosyjska flota wojenna, sądy morskie, morskie ustawodawstwo karne i dyscyplinarne, rosyjskie szkolnictwo wojskowe

\section{SUMMARY}

\section{Leszek Madej, The structure and the principles of functioning the judiciary of Russian war fleet in the period of 1867-1914 (part 1)}

In 1867 , the reform of the judicial system of the Russian navy was carried out, which was modelled on the structural solutions adopted in the land army. It introduced three degrees of jurisdiction. The crewed courts and the military naval courts looked into the cases in terms of their substantial contents, meanwhile the complaints and cassation protests against the sentence were aimed at the Main Military Naval Court. Court proceedings were held in a collegial and public prosecution. Defendants were guaranteed the right to defense and the court proceedings were based on the principles of equality of the parties and free assessment of evidence. The prosecutor's offices appeared in the Main Military Naval Court and the military naval courts, fulfilling prosecution functions. The obligation to conduct investigations fell on investigating judges. During ship cruises and military campaigns there were vessel courts and special committees, ruling on the basis of procedures different from those in the land naval courts.

Keywords: Russian war fleet, naval courts, naval penal and disciplinary legislation, Russian military education 


\section{PEЗЮME}

\section{Leszek Madej, Структура и принципы функционирования судебной системы военно-морского флота России в период с 1867 по 1914 год (Часть 1)}

В 1867 году была проведена реформа системы правосудия российского военно-морского флота, образцом для которой полужили структурные решения, принятые в сухопутных войсках. Реформа вводила трехинстанционную систему судебных органов. Экипажные и военно-морские суды занимались вопросами, непосредственно относящимися к их компетенциям, а кассационные жалобы и кассационные протесты направлялись в Главный военно-морской суд. Судебные процессы проводились в коллегиальном явном и публичном порядке. Обвиняемому было гарантировано право на защиту, а судебное разбирательство основывалось на принципе состязательности процесса и свободной оценке доказательств. В Главном военно-морском и военно-морских судах была создана прокуратура, выполняющая обвинительные функции. Обязанность проводить расследования возлагалась на следственных судей. Во время морских походов и военных кампаний действовали корабельные суды и специальные комиссии, принимающие решения на основе процедур, отличающихся от существующих в сухопутных морских судах.

Ключевые слова: Российский военный флот, морские суды, морское уголовное и дисциплинарное законодательство, Российское военное образование 